\title{
REFLECTION OF LABOR MARKET INTERESTS AND EXPECTATIONS IN EDUCATIONAL ORDER FOR CONTEMPORARY SCHOOL

\author{
Olga V. Rogach ${ }^{1 *}$, Elena V. Frolova ${ }^{2}$, Tatyana M. Ryabova ${ }^{3}$, Ekaterina A. Vetrova ${ }^{4}$
} \\ ${ }^{1,3,4}$ Assistant professor at the Department of Management and Administration. Russian State Social University, Moscow, \\ Russia, ${ }^{2}$ Doctor of Sociological Sciences, Docent, Professor of the Department of Management and Administration. \\ Russian State Social University, Moscow, Russia. \\ Email: ${ }^{1 *}$ rogach16@mail.ru, ${ }^{2}$ efrolova06@mail.ru, ${ }^{3}$ tani-87@inbox.ru, ${ }^{4}$ eavetrova@yandex.ru
}

\author{
Article History: Received on $21^{\text {st }}$ August 2019, Revised on $29^{\text {th }}$ September 2019, Published on $06^{\text {th }}$ November 2019
}

\begin{abstract}
Purpose of the study: The main objective of the study was the analysis of key labor market request content for the secondary education system, the level of employers' expectations compliance and actual learning outcomes, the research of resources and partnership interaction limitations of all interesting subjects in the process of an educational order development.
\end{abstract}

Methodology: The main method was the questionnaire survey of experts (individual entrepreneurs, the heads of industrial and structural divisions) of Moscow $(\mathrm{N}=316)$. The results of the expert survey showed the interest of employers in close cooperation with school in order to reflect the interests of the labor market in the educational order adequately.

Results: The most motivated group is a small business, the leaders of the lowest level in the sphere of trade and service, who directly interact with the school graduates in the process of their early start of labor activity. The experts noted the problems in the development of the social competencies among schoolchildren: excessive self-esteem, an excessive level of claims, low level of willingness to work in a team, the lack of such qualities as responsiveness and responsibility. The cooperation between school and employers is limited to traditional sponsorship practices. The interaction of employers and educational institutions is quite fragmentary, it depends on a variety of random factors (personal and situational motives), which does not ensure the stability and the effectiveness of social partnership.

Applications of this study: This research can be used for the universities, teachers, and students.

Novelty/Originality of this study: In this research, the model of Reflection of Labor Market Interests and Expectations in Educational Order for Contemporary School is presented in a comprehensive and complete manner.

Keywords: labor market, employer, secondary education, educational order, graduate competitiveness, social partnership.

\section{INTRODUCTION}

An objective increase of education institution role for the intellectual, socio-cultural and economic potential of Russia development (Rogach et al., 2017; Kasatkin, 2017) draws the attention of researchers to the specifics of an educational order content and development.

The educational order for a modern school is a formalized position of a manager for the quality of schoolchildren's education through the search for educational resources to develop and implement a plan for an educational situation change, in accordance with the requirements of the socio-economic reality. At present, it is customary to talk about two independent phenomena that determine the vector of educational policy - a state order and social order for education, which are interpenetrating and mutually determining ones.

The state educational order reflects the state main expectations regarding the results of training, which are recorded in concepts, standards, legislative acts, etc. In other words, a state order is an officially developed task of state authorities for the production of specific educational products by an educational institution.

In its turn, social educational order is "the mechanism for social necessity implementation, regulating the direction of educational activity for priority social problem solution". Unlike a state order, social order is the society's request to a modern school, which determines the set of requirements for a graduate personality and his socialization (Mendes \& Silva, 2018). A social educational order in the countries with market economy includes an entire complex of educational and related demands of population, as well as the requirements that are imposed by any social subjects to an educational institution or may be presented by them in the future.

\section{ANALYSIS OF PUBLICATIONS ON THE ISSUE}

An effective demonstration of educational service consumer requirements for learning outcomes is the factor of their quality improvement (Harrison et al., 2016). Nowadays the prevailing tendencies of socio-economic stagnation, the growing discontent of population with national education quality, necessitate the adaptation of the educational system to the labor market dynamics (Frolova E.V., Rogach O.V., 2017), as well as its bringing in line with the regional strategy of social and economic development.

The comparative analysis of official statistics showed that Russia has 53.5 thousand schools today, which is $18.8 \%$ less than in 2009. 10 years ago, there were 1.5 million teachers in Russia, and now their number has decreased by more than 
300 thousand. According to expert evaluations, 1-2 new teachers appear only in $60 \%$ of schools every year, in the rest ones the pedagogical staff is not only replenished by young but also has a natural decline (Kumari \& Alexander, 2018).

The quality of services provided by educational institutions is reduced significantly. This conclusion is confirmed by the results of the population survey, and by expert estimates. According to the poll conducted by the All-Russia Public Opinion Research Center, $70 \%$ of respondents believe that nowadays students are trained only for test passing, and therefore the quality of knowledge deteriorates. According to experts, "while maintaining good positions in the development of traditional academic skills, our school is becoming increasingly archaic in the information society and a high-tech economy". Zapp, M. (2017)

This provision confirms the quality monitoring conducted by independent researchers of secondary education, where PISA (Program for International Student Assessment) is the most authoritative study which is held every three years. The last study, in which Russia took part, refers to 2012, later our country refused independent monitoring, referring to the economic crisis. Despite the declared improvement of secondary education quality in 2012, Russia received an average score of 482, which allowed it to occupy only 39th place among 65 countries which participated in the study, leaving behind Mexico, Uruguay, Costa Rica, Thailand, Colombia, Peru, Chile and other countries which never had quality of education. Tozer, S., Senese, G. B., \& Violas, P. C. (2009)

The scientific literature emphasizes that the interaction with parents, local communities, and social sphere institutions is a key factor in educational system development. The analysis of publications on this topic illustrates various approaches to the evaluation of key actor activities in the educational space. Most works emphasize that a state is a compiler and the executor of an educational order and it determines the fundamental goals and the mechanisms of their implementation. The participants of educational process (parents, students, teachers) are directly involved in the internal environment subjects employers, higher education institutions, public organizations, associations that can consolidate the interests of educators (for example, teacher associations or school leaders) and other social groups. The scientific literature emphasizes that "the development of parent order mechanisms for educational institutions, the involvement of enterprise and organization representatives to work in school councils is the factor of educational service quality improvement. Kitschelt, H., Lange, P., Marks, G., \& Stephens, J. D. (Eds.)

The education system deals with a variety of order sources, the positions of different subjects can represent an alternative, and sometimes mutually exclusive strategies. The difficulty of these positions reconciling initiates the discussion of an employer's educational order issue as the most distant subjects since schoolchildren are not agents of the labor market for the most part because of their age. Nowadays, the orientation towards an employer order is not characteristic of secondary general education institutions, which traditionally treat the parental community as the leading subjects of social partnership, they consider that labor market representatives have the conditional status of educational space agents. Trinidad, C., \& Normore, A. H. (2005)

In foreign studies, partnership with business is seen as a strategic factor of education quality improvement (Zapp, 2017), student motivation development, the development of the most popular skills. The competitiveness of education is ensured through the involvement of an expert community in an educational order (Lobão \& Pereira, 2016), and primarily employers. The mechanism of social partnership acts as the leading mechanism that provides the necessary transformation of social relations that have developed in the system of Russian education, which is called upon to ensure the constructive harmonization of the interests among educational space agents in new conditions (Frolova \& Rogach, 2017, p.146).

The supporters of employer consideration as a social group that has the potential to influence the vector of secondary education development significantly, pay attention to the need to take into account their interests and needs in an educational order for the following reasons. First of all, this is due to the early start of youth labor activity. As a rule, since the first year, former schoolchildren are looking for a job, which means they face the requirements dictated by the labor market directly, and they do not have an appropriate capacity to present themselves even as an unskilled worker. If one acknowledges the success of a person in the labor market as the criterion for an educational order implementation evaluation and project it into general secondary education, then it is possible to assume with a reasonable degree of reliability that the task of this level is to create the conditions that ensure a child's development in respect of "some basic competencies necessary for him to become an owner of a personal human potential with a high use value".

The development of a constructive dialogue between employers and the educational sector will allow students to become more fully acquainted with the labor market situation and then reduce the proportion of graduates who do not want to work according to their field of experience. In modern conditions, the reforms of the educational system should be based on scientifically based forecasts of the labor market and economy development, whereas the discrepancy between the demand structure for education and modern technologies and production needs leads to significant imbalances.

The relevance of this issue is illustrated in the speeches of the first persons of the state, in particular, the President of Russian Federation V.V. Putin stressed in his speeches that if an entrepreneur thinks for the future, creates a long-term strategy for development, then "he must interact with school actively," and this should not be just an investment in new institution building. 
The Federal Law "On Education in Russian Federation" notes that the basic principle of relation legal regulation is the democratic nature of education management, the provision of rights for teachers, students, the parents of schoolchildren to participate in the management of educational organizations. However, the specified issue has no detailed regulation in the specified legislative act. The absence of a regulatory framework governing the participation of business in the management of education significantly narrows the "legitimate" practices of employer attraction to an educational order development. The most common forms of participation are patronage, sponsorship, the organization of practice and professional orientation. The participation of employers in the collegiate bodies of school management, and in the development of an educational order, refers rather declare than to real practices of social partnership.

Business representatives are aware more and more of cooperation importance with the school. The following are the main incentives for partnership establishment between employers and general education schools: the possibility of PR (a positive image development) and the expansion of its consumer audience, the program of corporate social responsibility, the strategic tasks of future employee development, own growing children, etc. Most often the practices of potential employer participation in an educational order development take place in medium-sized and small urban or rural settlements, whose socio-economic life centers are around one or several enterprises (Rogach et al., 2017). In this case, one can organize its own production near school, which allows children to gain working experience. There are also examples of large corporation program implementation focused on their brand promotion and an extensive base development for the inflow of future employees and product consumers. However, these practices illustrate, rather, the experience of employers' participation in youth vocational guidance programs than in the process of an educational order development for a school.

The analysis of interaction experience between general education institutions and labor market representatives testifies to its fragmentation and insufficient effectiveness. We believe that the reasons for the situation are the stereotypes of the pedagogical community, the strict framework for educational process regulation, and the reluctance of employers to "dissipate" their attention between production profitability increase and the need to distract workers to work with schoolchildren, as well as a number of technical difficulties for this process organization. The situation is exacerbated by significant limitations in normative documents, the rigidity of managers' thinking, the lack of adequate articulation instruments, the coordination and the reflection of educational space leading agent needs for the preparation of schoolchildren.

\section{METHODOLOGY OF THE STUDY}

Thus, the scientific literature mainly deals with the interaction of the labor market and higher professional education, which concerns school, but the focus here is on the state, local authorities and family role. In this regard, the scientific novelty of the presented material is characterized by the analysis of the main areas of cooperation between employers and secondary education. Taking into account the controversial nature of labor market impact on the content of an educational order, the scientific novelty consists of the analysis of employer interest and expectation reflection in an educational order for a modern school. The analysis of resources and the limitations of partnership interaction of all interested persons in the process of an educational order development are of practical significance.

The purpose is to analyze the content of an employer's educational order, their interests, and expectations in the process of student preparation, the evaluation of education quality in terms of modern labor market requirements.

The study was based on the hypothesis of a modern educational system shift from labor market needs, expressed in the presence of significant disagreements between the requirements imposed by employers on the competencies and qualities of a high school graduate and the actual results of training.

In order to test the hypothesis put forward by the author team, they studied the opinion of 316 experts (individual entrepreneurs, the heads of the branch and structural divisions) of the city of Moscow. The interviewed experts are the representatives of such spheres of activity as construction (78 people), state and municipal administration (74 people), trade (57 people), service (56 people), economy and finance ( 31 people), health (16 people), etc.

The questionnaire survey was used as the leading method of the study.

The interviewed potential employers included the heads of small and medium-sized business organizations, the heads of state and municipal government body divisions and business structures of various profiles, as well as the heads of working groups and teams.

\section{RESULTS}

First of all, potential employers gave the assessment of the current state of school education, according to which $75.6 \%$ of respondents recognized the need to modernize the foundations of Russian educational sector operation. Despite a significant number of respondents who found it difficult to assess the functioning and the development of modern school educational services in general, the question "Does modern education meet your requests for the education of children?" was answered as "no" unambiguously $(78.4 \%)$.

It was suggested to specify the requirements they set for the content of school education to reflect the expectations of potential employers better. The rating of the received answers is headed by "the acquisition of the necessary knowledge 
base and skills" (86.5\%), this position is significantly inferior to the second requirement in terms of references, namely "the development of independent and critical thinking" (66.7\%). "The preparation for independent and labor activity" $(64.3 \%)$ and "the development of a stable labor motivation" (60.6\%) occupy a very important place in the employer's requirement system. In practice, the career guidance work at schools is limited to the in-depth study of humanitarian or technical subjects and does not develop appropriate social, communicative and other skills for students.

The leaders, while determining the criteria which a modern school graduate should match, drew attention to the need for such qualities as "to be able to build the relationships with different people" (72.3\%); "To bear individual and social responsibility" (63.8\%); "Be able to formulate a life goal and build the ways of its achievement" (51.6\%) in addition to the traditionally expected "to have good bases of knowledge and skills" (80.8\%). Thus, not only the subject-information competencies (to have good knowledge) are important for potential employers, but also social and communicative skills. These requirements are conditioned by modern socio-economic processes. An extremely dynamic labor market requires a constant update of knowledge and the acquisition of new competencies. Accordingly, knowledge itself does not provide competitiveness in the modern world. The decisive factor is the motivation to qualification improvement, social and communication skills and a high level of personal responsibility. "Public access to information and almost zero cost of its storage and transmission" (Donnelly, 2013) actualizes the significance of individual value-motivational attitudes.

In the course of the study, they revealed that the ranking of criteria which a modern school graduate should meet is closely dependent on the company industrial profile and the level of hierarchy that a potential employer occupies in a company. For example, the construction business in Moscow is characterized by the presence of the following relationship: the higher a leader's level in the service hierarchy, the less the requirements, and the formulation itself has a more generalized form (for example, to have basic knowledge of the modern world), while the leaders of the lower ranks have very high requirements for school leavers. Almost the same situation is characteristic of trade sphere. The heads of small businesses carrying out trade activities are characterized by the highest demands among all the experts interviewed. Thus, those spheres of activity where an employer has direct experience of communication with a school graduate are characterized by more essential and specific requirements for training content. It can be assumed that senior executives interact with more qualified and experienced personnel, mostly the graduates of higher education institutions, respectively, such a distance makes it possible to maintain a soft attitude to the evaluation of training results at a secondary school.

This regularity actualizes the practical significance of the obtained study results. The requirements from employers for school leavers are determined not so much by a general, philistine assessment of education quality as by the direct experience of young people hiring who carry out early work in those areas where special education is not required (trade, servicing, etc.). The results obtained by us illustrate the segment of expert opinions directly related to the problem under study, whose experience allows us to comprehend the specifics and the content of former schoolchildren training critically.

The following question was posed: "What knowledge and skills are necessary for a modern school graduate?". And the following results were obtained. The respondents' rating is led by the traditional "independence and initiative" (72.8\%), "availability of labor motivation" (56.1\%) and "modern world knowledge" (44.8\%). Also, the low culture of communication and the lack of legal literacy cause high discontent (67.2\% and $39.2 \%$, respectively).

According to the results of the study, the comparative analysis was made concerning the relevance of a school graduate knowledge and skills among the representatives of the modern labor market and the degree of their development among students at educational institutions.

According to the obtained results, school graduates meet the requirements of potential employers (mathematical and literary literacy) for a number of indicators, and even significantly exceed these requirements in some indicators (naturalscience literacy and language skills). However, a number of personal positions of schoolchildren have a significant gap (the culture of communication, independence, and initiative, the ability to conduct analysis, set goals, etc.). These indicators are characterized by the greatest degree of discrepancy between the expectations of employers and the actual results of training. The received data confirm the previously stated thesis that the main issues of an educational order implementation in modern conditions are the development of student social and communicative skills, the "system of values and moral foundations, fixed in positive behavioral models".

The development of rigid indicators to assess the activities of a teacher and a schoolchild in the course of the USE focuses the school system of education solely on the transfer of subject knowledge and the memorization of the required information. The teaching work in modern conditions is reduced to the training for the implementation of standard tasks. The development of moral qualities of a person, social and communication skills, the student motivation on new knowledge is difficult enough for a Russian teacher in the conditions of time deficit and the dominance of a quantitative, formalized approach to the evaluation of his activities. The consequences of these tendencies include the growing contradiction between the expectations of educational space key subjects from intellect, social and communicative skills, the moral qualities of students and the actual results of education in a modern school.

Answering an open-ended question about the key problems characterizing the development of basic social competencies of schoolchildren, the experts highlighted the following points: excessive self-esteem, an excessive level of claims, a low level of readiness for teamwork, the lack of such qualities as responsiveness, responsibility, discipline, and respect for 
seniors. The obtained results are confirmed by other studies, which note that "the presence of an overestimated self-esteem of abilities and intelligence among modern schoolchildren plays a cruel joke with its owners. It leads to the first serious defeats without the contribution to the real choice of life prospects".

The results of the employer survey illustrate a number of trends. On the one hand, a modern school does not implement the economic requirements of an educational order, the individual competencies of students (independence, initiative, labor motivation) are not developed sufficiently. On the other hand, the fundamental values of Russian culture are leveled, the traditions of the Soviet education system are lost, which coped with the tasks of student moral qualities development quite successfully. The goals of competitive personality development in a state educational order are reduced in practice to the development of a pragmatic orientation toward success, and overestimated self-appraisal of own abilities, individualism to the detriment of such skills as teamwork, the respect for authorities and the readiness for compromise.

It is natural that employers consider government officials as the main subject of influence on the content of a schoolchild training $(72.3 \%)$. The regional $(32.1 \%)$ and local $(7.9 \%)$ authorities have significantly fewer influence capabilities from the expert point of view. The interests of other subjects (employers, parents, students), their expectations and requests for the formulation of an educational order are demanded poorly, according to the opinion of the interviewed experts. In modern conditions, the state management structures remain the key subject determining the priorities for the education sector development. A high level of centralization and standardization in educational activities develops a fairly rigid management system, in which an open interaction with all interested participants is not considered as the priority for efficiency. These trends reflect the situation of information closeness among authorities typical for Russian reality, their distancing and a low level of readiness to take into account the opinions of the population in the process of making managerial decisions. The state-public nature of education sphere management remains mainly a political declaration, the involvement of parents and employers for a social order development to a school is indirect and often imitative one.

In particular, the cooperation between school and employers is limited to the traditional practices of sponsorship. According to the experts interviewed, the heads of general education organizations are interested in such forms of interaction. Even the measures for professional orientation are demanded much less. As for such aspects as the participation in the determination of a curriculum component determination, the diagnosis and the development of technologies for student competence formation, the development of their individual educational trajectories, then they are not entirely realistic from the point of view of their implementation according to the opinion of employers. To be fair, it should be noted that in the context of educational process strict regulation, school principals do not have sufficient opportunities to provide real variability of educational programs. Describing the needs of the school in cooperation with the labor market, the employers noted such problems as "consumer attitudes toward business on the part of educational institution heads", "the directors are aimed at the cooperation with resource organizations", "and the partnership is reduced to the seeking of finance for school needs."

Thus, modern employers are distanced not only from the development of educational process variable components but even from the vocational guidance system of students. Thus, "the process of educational service market and the labor market coordinated development is broken now", the work on the professional self-determination of schoolchildren "is based on enthusiasm at best and is spontaneous one".

According to the survey, only $3.7 \%$ of representatives of business structures implement a real practice of partnership with specific educational institutions. Like experts in general, only those who evaluate the prospects for cooperation hypothetically, and those who implement this in practice, are unanimous in their assessments. The qualitative indicators of such a partnership are not high and are reduced to the obtaining of sponsorship and other support.

Among the experts who actually cooperate with educational institutions, the overwhelming majority of respondents noted an important role of the personal factor in its initiation. So, an employer often acts as a pupil's parent, and this motivates him to sponsorship provision additionally. Other options include "an active position of an educational institution director", "I studied here, now I want to help my school." Thus, the rare practices of cooperation are quite fragmentary, spontaneous and depend on a variety of random factors, which does not ensure their stability and effectiveness.

Due to a significant discrepancy between the content of the secondary school educational order and the requirements and the interests of potential employers, the respondents were asked to answer the question concerning the need to develop a social request for education. According to the information received, $66.2 \%$ of the labor market representatives support the development of the social educational order for school, while $17.9 \%$ of the respondents consider this step to be an inappropriate one. It is noteworthy that the representatives of small business, service, and trade, who interact directly with young people starting their early labor activity, are most interested in a social order development for school.

At that, $39.9 \%$ of potential employers state the need to ensure closer cooperation with school in order to reflect the interests of the labor market in a social educational order adequately. At the same time, it is important to understand that there is no unified position on the transformation of a modern school educational order among business structures, since even before long the secondary education has not been considered by legislators, let alone employers as a significant step for competitive expert development. However, an undoubted increase of education role in the life of modern society and the 
reorientation of Russia to the reproduction of new priorities for social and economic development requires a higher level of adaptability of school training results to the labor market needs. Rogach, O., Ryabova, T., \& Frolova, E. (2017)

\section{DISCUSSION AND CONCLUSION}

The participation of employers in the educational order for a secondary school is one of the most controversial issues, given the traditional approach in which the development of professional competencies that meet the needs of the labor market is the prerogative of higher education exclusively.

The results of the study show that the labor market, which is currently being considered as a potential participant in the development of an educational request for a modern school, has the potential and the desire to become an active subject of education order transformation.

In the course of the performed study, they confirmed the hypothesis of the distance between the modern educational system and the labor market needs, expressed in the presence of significant discrepancies between the requirements imposed by the employers on the competencies and qualities of a high school graduate and the actual results of training. The regularity of the traditionally low influence of employers on an educational order development for a secondary school is preserved.

According to the results of the study, the author's team determined the following trends:

1. The addressing of potential employer attention to the origins of competitive expert development, namely, to the content of an educational order for a modern school. The most interested group is the small business, the leaders of the lowest level in the sphere of trade and service, who interact with the school graduates directly in the process of their early commencement of work.

2. The increase of labor market representatives focused on social partnership with the subjects of the school education space. However, the cooperation practices are limited to paternalistic models in which employers are perceived only as the providers of resources.

3. On the one hand, the modern school does not implement the social and economic requirements of employers fully (the problems in the development of such competencies as independence, initiative and labor motivation). On the other hand, insufficient attention is paid to the formation and the development of student moral qualities.

Thus, on the basis of the author's employer survey toolkit, the main regularities and the trends of labor market and the modern school interaction are determined, which broadens the theoretical analysis on the modernization of secondary education, the development of a high level of competitiveness among young professionals on the basis of an effective work on vocational guidance, the development of continuous educational trajectories corresponding to the labor market needs.

The obtained results can be used to develop partner interactions between employers and secondary general education, to ensure a higher quality of schoolchildren training in accordance with the modern requirements of the labor market. According to the information received, the established discrepancy between the state of an educational order content and the requirements and the interests of potential employers is accompanied by the lack of an adequate "springboard" to establish the partnerships between potential employers and educational institutions (the gaps in legislation, the reluctance of the school to treat employers as the customers of educational services, the lack of effective interaction mechanisms, etc.). In the conditions of modern school education inability to eliminate the "failure" in the development of those properties and qualities of a personality that are demanded by labor market today (initiative, work orientation, communication culture, the ability to get along with people, etc.), this circumstance is seen as a significant barrier for the future achievement of personal and career ambitions by schoolchildren, provoking not only the decline of Russia labor potential quality, but also the number of deviations increase.

\section{REFERENCES}

1. Agafonov N. N., Breach R. A., Gadaev D. N. (2009) The maintenance of public order education system: effective mechanisms of how to design a professional environment and mechanisms for the presentation of the results of the execution of a public procurement professional community: Materials of sociological research. Perm: Laboratory of sociological research and social design of PSPU.

2. Antikainen A. (2010) The Capitalist State and Education // Current Sociology. 58, 4. - P. 530-550. https://doi.org/10.1177/0011392110367988

3. Bailey T. (1991) Jobs of the Future and the Education They Will Require: Evidence from Occupational Forecasts // Educational Researcher. - March 20: 11-20, https://doi.org/10.3102/0013189X020002011

4. Cheremnykh A.M. (2008) The Role of the business community and nonprofit organizations in the development of school education. Vestnik of Udmurt University. A Series "Philosophy. Psychology. Pedagogy.» No. 1. p. 21-34

5. Donnelly K., Rizvi S., Barber M. (2013) On the Eve of avalanche. Higher education and the coming revolution (translated from English. N. Misinai) // Questions of education. - No. 3. - P. 152-229. https://doi.org/10.17323/1814-9545-2013-3-152-229 
6. Farhutdinov N. G., Evstigneeva N. In. Kurakin D. Y., Malik V. M. (2015) Model of managing secondary schools in the conditions of reforms: experience of sociological analysis // Questions of education. - No. 2. - P. $196-219$. https://doi.org/10.17323/1814-9545-2015-2-196-219

7. Fakhrutdinova E.V., Fakhrutdinova A.V., Yagudin R. H., Vishnjakov N. I. (2015) The Needs Of The Russian Federation Labor Market In The Workforce With Different Levels Of Education // Procedia - Social and Behavioral Sciences. - 191.- p. 2515 - 2518. https://doi.org/10.1016/j.sbspro.2015.04.593

8. Frolova E.V., Rogach O.V. (2017) Municipal-private partnership in education: the infrastructure aspect // the Economic and social changes: facts, trends, forecast. Vol. $10 . \quad$ No. 1 (49). p. $145-160$. https://doi.org/10.15838/esc.2017.1.49.8

9. Frolova E.V., Rogach O.V. (2017) Economics of education: from free benefits to the commercialization of educational services. Social policy and sociology. № 5 (124) 2017. C. 165-174. https://doi.org/10.17922/20713665-2017-16-5-167-174

10. Golovchin M. A. (2009) Questions of development of public administration in educational institutions of the city / M. A. Golovchin / / problems of territory development, No. 1.

11. Gubanova E. V., Surkov A. V. (2011) Federal state educational standard: identify the order // Narodnoe obrazovanie. - No. 7. - P. 116-123.

12. Harrison K., Taysum A., McNamara G., O'hara J. (2016) The degree to which students and teachers are involved in second-level school processes and participation in decision-making: an Irish Case Study [Electronic resource] // Irish Educational Studies. - - Mar 2016.

13. Hutchinson J., Dickinson B. (2014) Employers and schools: How Mansfield is building a world of work approach. [Text] / / Local Economy. - vol. 29, 3. p. 257-266. https://doi.org/10.1177/0269094214528158

14. Kasatkin P. I. (2017) Education in the context of the values of national culture. Social policy and sociology. Tom: 16Номер: 3 (122), p. 188-196. https://doi.org/10.17922/2071-3665-2017-16-3-188-196

15. Klyucharev G. A. (2015) «Gap» of education and labor market: expert opinions// Sociological research. No. 11. P. $49-56$

16. Komívesa P., Dajnokib K. (2015) Ranking systems as the connection between the higher education and the labour market in Hungary [Text] // Procedia Economics and Finance. 32. - P. 292 - 297. https://doi.org/10.1016/S2212$\underline{5671(15) 01394-5}$

17. Kuzminov Y., Frumin I.D., Zaharov A.B. (2011) Russian school: an alternative to modernization from above // Questions of education. - No. 3. - p. 5-53. https://doi.org/10.17323/1814-9545-2011-3-5-53

18. Manna P., Harwood T. (2011) Governance and Educational Expectations in the U.S. States [Text] // State policies \& Policy Quarterly. - 11, 4. - P. 483-509. https://doi.org/10.1177/1532440011421302

19. Medvedeva N.V. (2015) The system of state-public management of education in the Russian Federation: tendencies and problems of development // Social policy and sociology. Vol. 14. No. 2 (108). -P. 47-55. https://doi.org/10.17922/2071-3665-2015-14-2-47-55

20. Pinsky A. A. (2004) Public participation in school management: School boards/ M.: Alliance Press.

21. Pryazhnikova E. J. (2011) Professional self-determination of schoolchildren in modern Russia // the Collections of conferences. Issue \# 7. - P. 229-236

22. Rogach O.V., Ryabova T.M., Frolova E.V. (2017) Analysis of problems in managing the innovative development of secondary education in modern Russia. Integration of Education. Vol. 21,no. 4. P. 669-682. https://doi.org/10.15507/1991-9468.089.021.201704.669-682

23. Rogach O. V., Frolova E. V., Ryabova T. M. (2017) Academic Competition: Rating Race. European Journal of Contemporary Education, 6(2), pp.297-307. https://doi.org/10.13187/ejced.2017.2.297

24. Shabunova A. A., Golovchin M.A. (2012) Evaluation of education development in municipal territories// problems of territory development. -No. 1. - P. 91-99.

25. Shafranov-Kutsev G. F. (2015) Modern challenges and the reality of career guidance in the system of "school University - labor market" // Sociological research. - No. 1. - S. 120-128.

26. Shkurov A. Yu. (2011) Creation and development of public administration at the level of educational institution // proceedings of PSU. V. G. Belinsky. No. 24.p. 869-872.

27. Sukhanov E. A. (2004) Tutor support for the development of educational order / open education and regional development: how to build educational space // Collection of scientific works. Tomsk: Tomsk CSTI. p. 71-77.

28. Theoretical and methodological approaches to the analysis of educational policy in the context of reforms of Russian education of the twentieth century (2013)// Problems of modern education. No. 4. - P. 21-34

29. Turnbull A., Turnbull R., Erwin E.J., Soodak L.C., \& Shogren K.A. (2015) Families, professionals, and exceptionality: Positive outcomes through partnerships and trust (7th ed.). / Upper Saddle River, NJ: Merrill Prentice Hall.

30. Tutan A. (2016) Labour market outcome for formal vocational education and training in India: a Safety net and beyond // IIMB Management Review. - 28. - P. 98-110. https://doi.org/10.1016/j.iimb.2016.05.002

31. Yakushev M. V. (2014) State and social orders in the field of education as a content-target guide in the design of the textbook // Pedagogical journal. No. 4. P. 10-29.

32. Zapp M. (2017) The World Bank and Education: covering (through) knowledge // International Journal of Educational Development. - Volume 53. - P. 1-11. https://doi.org/10.1016/j.ijedudev.2016.11.007 
33. Zhelezov B. V., Kudyukin p. M., Shuvalova O. R. (2009) The Effectiveness of the education system: the view of the consumer of educational services // Voprosy obrazovaniya. - No. 2. - P.187-210

34. Zamolotskikh E. G. (2010) The Family and school - social partners (historical aspect)// Pedagogics and psychology of education. - No. 4.- p. 5-11.

35. Boswell, T. E. (1986). A split labor market analysis of discrimination against Chinese immigrants, 18501882. American Sociological Review, 352-371. https://doi.org/10.2307/2095307

36. Streeck, W., \& Schmttter, P. C. (1991). From national corporatism to transnational pluralism: organized interests in the single European market. Politics \& Society, 19(2), 133-164. https://doi.org/10.1177/003232929101900202

37. Jensen, M. C., \& Zimmerman, J. L. (1985). Management compensation and the managerial labor market. Journal of Accounting and Economics, 7(1-3), 3-9. https://doi.org/10.1016/0165-4101(85)90025-4

38. Coleman, J. S. (1991). Matching processes in the labor market. Acta sociologica, 34(1), 3-12. https://doi.org/10.1177/000169939103400101

39. Blossfeld, H. P. (Ed.). (2008). Young workers, globalization and the labor market: Comparing early working life in eleven countries. Edward Elgar Publishing.

40. Traxler, F. (1993). Business associations and labor unions in comparison: theoretical perspectives and empirical findings on social class, collective action and associational organizability. British Journal of Sociology, 673-691. https://doi.org/10.2307/591416

41. Gabel, M. J. (2009). Interests and integration: Market liberalization, public opinion, and European Union. University of Michigan Press.

42. Hoy, W. K., \& Miskel, C. (Eds.). (2006). Contemporary issues in educational policy and school outcomes. IAP.

43. Carrim, N. (2001). From teachers to educators: Homogenising tendencies in contemporary South African educational reforms. International Journal of Educational Development, 21(1), 45-52. https://doi.org/10.1016/S0738-0593(00)00012-2

44. Reynolds, D. (2002). School effectiveness, school improvement and contemporary educational policies. In Education policy and contemporary politics (pp. 65-81). Palgrave Macmillan, London. https://doi.org/10.1057/9781403920010_5

45. Hanson, E. M. (1996). Educational administration and organizational behavior. Allyn \& Bacon, A Simon \& Schuster Company, 160 Gould Street, Needham Heights, MA 02194-2310..

46. Hanushek, E. A., Schwerdt, G., Woessmann, L., \& Zhang, L. (2017). General education, vocational education, and labor-market outcomes over the lifecycle. Journal of Human Resources, 52(1), 48-87. https://doi.org/10.3368/jhr.52.1.0415-7074R

47. Thurow, L. C. (1972). Education and economic equality. The public interest, 28, 66.

48. Rouse, C. E. (2005, October). The labor market consequences of an inadequate education. In symposium on the Social Costs of Inadequate Education, Teachers College Columbia University..

49. Grubb, W. N. (1996). Working in the Middle: Strengthening Education and Training for the Mid-Skilled Labor Force. Jossey-Bass Publishers, Inc., 350 Sansome Street, San Francisco, CA 94104-1310.

50. Lang, K., \& Manove, M. (2011). Education and labor market discrimination. American Economic Review, 101(4), 1467-96. https://doi.org/10.1257/aer.101.4.1467

51. Bishop, J. H., \& Mane, F. (2004). The impacts of career-technical education on high school labor market success. Economics of education Review, 23(4), 381-402. https://doi.org/10.1016/j.econedurev.2004.04.001 